(i)

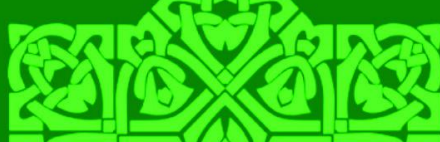
tह

Muhammad Yusuf, Baharuddin, Mardan The Quranic Hermeneutics Approach to Gender Equality in Amina Wadud Muhsin's View

A. Zamakhsyari Baharuddin التظاهر بالشعار ات القومية في شعيرة الحج و العمرة

Andi Muhammad Ridwan, Baso Pallawagau Falsafah Al-Wujudiyyah Al-Sufiyyah: Asluha Al-Dini wa Manqif Al-Ulama Minha

Muhammad Widus Sempo, Norita Binti Md Norwawi, Hasyim Haddade, Yousuf Mahbubul Islam, Noorhayati Binti Hasyim Unbelievers' Mental Model and Behavioural Disorders Based on Their Queries in The Al-Baqarah Chapter

Sri Sunantri, Achmad Abubakar, Kamaluddin Abu Nawas, Firdaus Methodology of Interpretation of Muhammad Amin Al-Syinqiti

Amirullah, Andi Achruh AB. Pasinringi, Rahmawansyah Sahib The Transformation of The Muamalah Fiqh Akad at Saga Abepura-Papua Mall During The Covid 19 Pandemic

Irwan Misbach Siri'Na Pacce Culture in Retailer Based on Islamic Perspective Business Ethics

Abd. Rahman R Family Resilience in Islamic Perspective (A Case Study of Parent and Child Interaction Behavior in The District of Somba Opu Gowa)

Vol. 20 No. $2 / 2020$ 


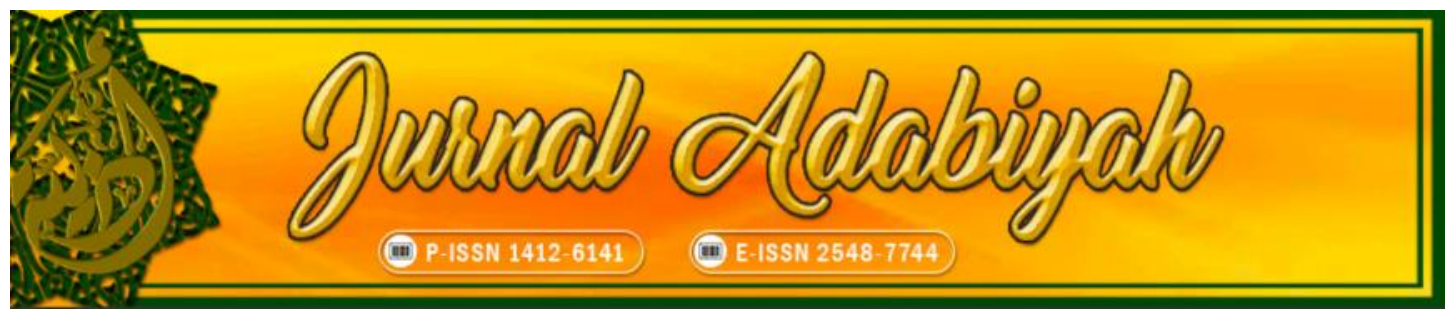

Theme: Islamic Studies

VOLUME 20 NO. 2 DECEMBER 2020

\section{EDITOR-IN-CHIEF}

Barsihannor, Alauddin State Islamic University, Indonesia

\section{INTERNATIONAL EDITORIAL BOARD}

Nuri Emmiyati, Alauddin State Islamic University, Indonesia

Minako Sakai, Australian National University (ANU), Australia

Abd Rauf Muhammad Amin, Fakulti Syariah Kupu SB Brunei Darussalam, Brunei Darussalam

Muhammad Widus Sempo, Universiti Sains Islam Malaysia, Malaysia

Salih Yousif Sharaf Mohamed, Al-Gazera University, Sudan

Aishah Waenaha Waemamah, Academy of Islamic and Arabic Studies Princess of Naradhiwas University - Thailand, Thailand

\section{EXECUTIVE EDITOR}

Umar Thamrin, Alauddin State Islamic University, Indonesia

\section{MANAGING EDITOR}

Nasrum, Alauddin State Islamic University, Indonesia

\section{EDITORS}

Rosmah Tami, Alauddin State Islamic University, Indonesia Haniah Haniah, Alauddin State Islamic University, Indonesia Zaenal Abidin, Alauddin State Islamic University, Indonesia

Awaluddin Syamsu, Universitas Muslim Indonesia

Ahmadi Usman, UIN Syarif Hidayatullah Jakarta, Indonesia

Baso Pallawagau, Alauddin State Islamic University, Indonesia

Muhammad Azwar, UIN Syarif Hidayatullah Jakarta, Indonesia

Muh. Saleh Syamsuri, Alauddin State Islamic University, Indonesia

Andi Satrianingsih, Muhammadiyah University, Indonesia

Syahruni - Junaid, Alauddin State Islamic University, Indonesia

Rabiatul Adawiah, Majene Islamic State College, West Sulawesi, Indonesia, Indonesia

Chusnul Chatimah Asmad, Alauddin State Islamic University, Indonesia

Nur Arifin, Alauddin State Islamic University, Indonesia

\section{IT SUPPORT}

Taufiq Mathar, Alauddin State Islamic University, Indonesia

\section{LANGUAGE ADVISOR}

Kustiwan Syarief, UIN Syarif Hidayatullah Jakarta, Indonesia Muh. Saleh Syamsuri, Alauddin State Islamic University, Indonesia

\section{COVER DESIGNER}

Nur Arifin 


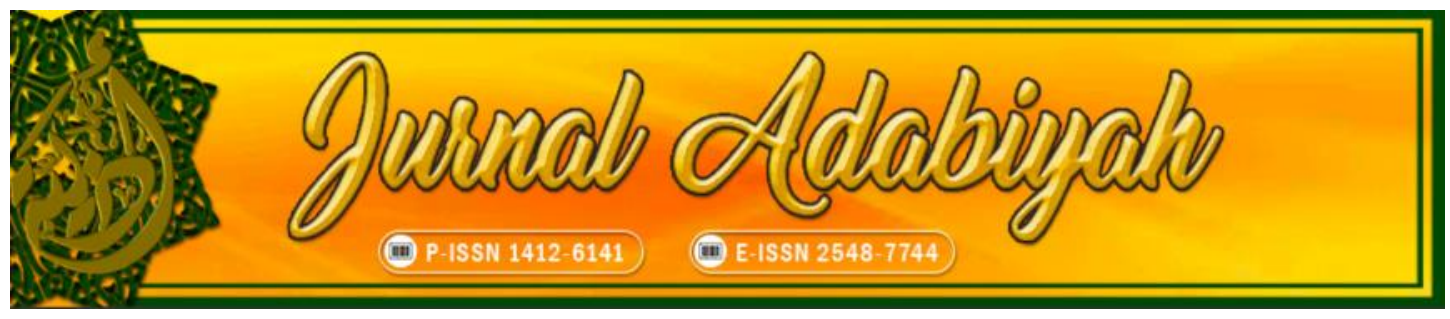

\section{Jurnal Adabiyah:}

This journal receives a national accreditation from Ministry of Research, Technology, and Higher Education Republic of Indonesia, Nomor 10/E/KPT/2019 on April 4, 2019 with the SINTA score: S2.

The Journal has been published by the Faculty of Adab and Humanity of Alauddin State Islamic University, Makassar, since 1997 and has been online since 2016 with the main themes on Humanities and Islamic Studies with the emphasis on interdisciplinary and intertextuality approach.

This journal are published twice a year, on June and December. The themes related to Islamic Studies are textual studies, scriptural traditions, Islamic law, and theology; and those related to Humanities are language, literature, history, and culture.

The journal of Humanities and Islamic Studies will provide the online collection of articles from 1997 up to now. The most updated information can be found on the website. 


\section{Table of Contents}

Muhammad Yusuf, Baharuddin, Mardan

214-237

The Quranic Hermeneutics Approach to Gender Equality in Amina Wadud Muhsin's View

A. Zamakhsyari Baharuddin

التظاهربالشعارات القومية في شعيرة الحج والعمبرة

261-285

Andi Muhammad Ridwan, Baso Pallawagau

Falsafah Al-Wujudiyyah Al-Sufiyyah: Asluha Al-Dini wa Mauqif AlUlama Minha

Muhammad Widus Sempo, Norita Binti Md Norwawi, Hasyim Haddade, Yousuf Mahbubul Islam, Noorhayati Binti Hasyim ................... 286-299 Queries in The Al-Baqarah Chapter

Sri Sunantri, Achmad Abubakar, Kamaluddin Abu Nawas, Firdaus. 300-319 Methodology of Interpretation of Muhammad Amīn Al-Syinqiti

Amirullah, Andi Achruh AB. Pasinringi, Rahmawansyah Sahib

The Transformation of The Muamalah Fiqh Akad at Saga Abepura-Papua Mall During The Covid 19 Pandemic

Irwan Misbach

Siri' Na Pacce Culture in Retailer Based on Islamic Perspective Business Ethics

Abd Rahman R

Family Resilience in Islamic Perspective (A Case Study of Parent and Child Interaction Behavior in The District of Somba Opu Gowa) 


\title{
METHODOLOGY OF INTERPRETATION OF MUHAMMAD AMIN AL-SYINQITTI
}

Sri Sunantri ${ }^{1}$, Achmad Abubakar ${ }^{2}$, Kamaluddin Abu Nawas ${ }^{3}$, Firdaus ${ }^{4}$ Islamic Studies Institute of Sultan Muhammad Syafiuddin Sambas, Indonesia ${ }^{1}$ Alauddin State Islamic University of Makassar, Indonesia ${ }^{2,3,4}$ Email: nantri636@gmail.com ${ }^{1}$, achmadabubakar.aa@ gmail.com², kamaluddinab@gmail.com ${ }^{3}, \underline{\text { firdaus.malik@uin-alauddin.ac.id }}$

\begin{abstract}
Interpretations of the modern period are very diverse in terms of methodology. One of them is a work of interpretation from Muhammad

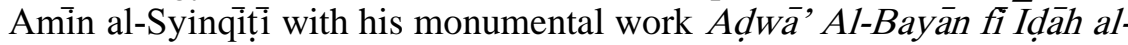
Qur'an bi Al-Qur'ān. Al-Syinqị̂i is a Maliki scholar active in the field of education and teaching, preacher and a judge. The interpretation aims to find the meanings, wisdom and laws contained in the Qur'an, and invite Muslims to return to the Qur'an in living their lives. This study describes the methodology of its interpretation which includes the general systematic interpretation, the methods used in interpreting the Qur'an include the methods of tahlïi, Muqārin, and ijmāti. The analysis of tahlili and muqārin on àyăt al-ahkām, while the ijmāti method in eschatological verses and verses of nature, other than àyat al-ahkām. The form of interpretation is bi al-ma'siur and bi al-ra'yí. The form of interpretation is inseparable from the sources it uses, namely originating in the Qur'an, hadith, qaul sahābah, ulama convention, poetry, and qirā'at $s a b^{\prime} a h$. The interpretation of the Qur'an with the Qur'an (verse by verse) becomes dominant in its interpretation. While the interpretation style is fiqh and languages style.
\end{abstract}

Keywords: Muhammad Amīn Al-Syinqițī; Methodology; Interpretation

$$
\text { نبذة مختصرة }
$$

تختلف التفسيرات الحديثة بشكل كبير من وجهاة نظر منهجياة .واحد

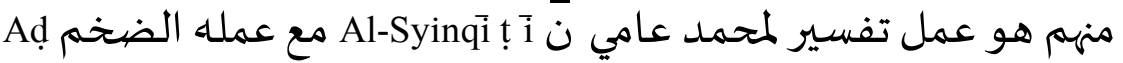

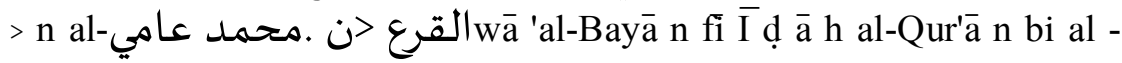

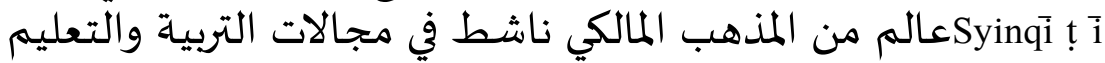

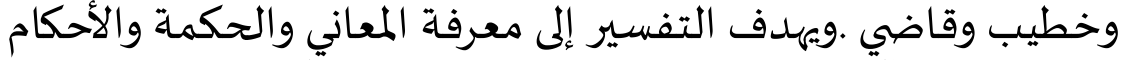

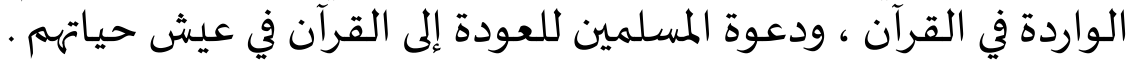

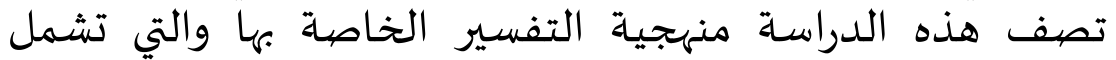

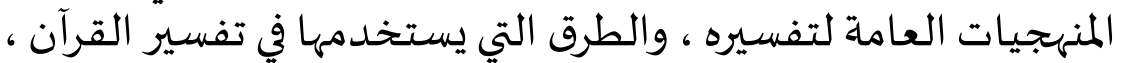

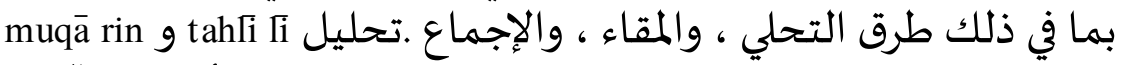
ij à yā t al-ahkā m 


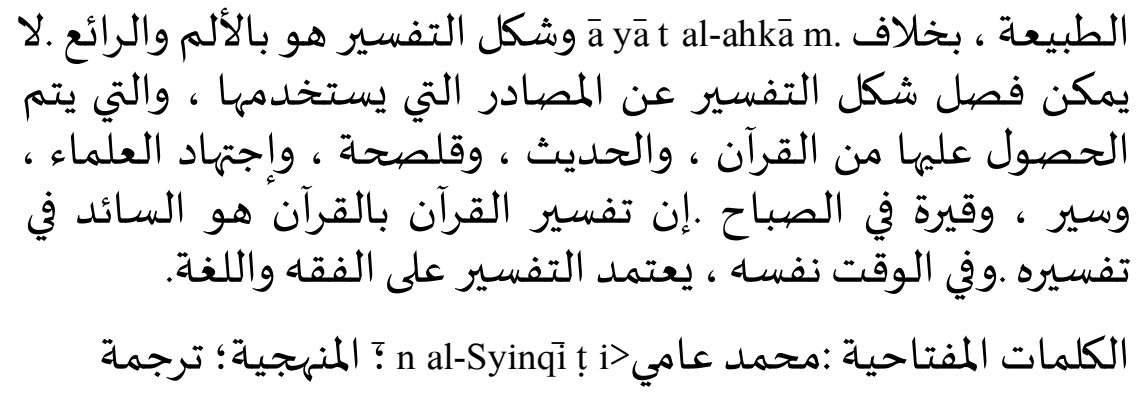

\begin{abstract}
Abstrak
Penafsiran masa modern sangat beragam dari segi metodologi. Salah satunya adalah sebuah karya penafsiran dari Muhammad Amīn al-

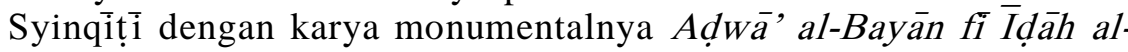
Qur'àn bi al-Qur'an. Muhammad Amin al-Syinqiți adalah seorang ulama bermazhab Maliki yang aktif pada bidang pendidikan dan pengajaran, pendakwah dan seorang hakim. Penafsirannya bertujuan untuk menemukan makna-makna, hikmah dan hukum-hukum yang terdapat dalam al-Qur'an, dan mengajak umat Islam kembali pada al-Qur'an dalam menjalani hidup. Kajian ini mendeskripsikan metodologi tafsirnya yang mencakup sistematika umum penafsirannya, metode yang digunakannya dalam menafsirkan alQur'an diantaranya metode tahlīî, Muqārin, dan ijmāli. Analisis tahlìlì dan muqārin pada àyăt al-ahkām, sedangkan metode ijmāli pada ayat eskatologis dan ayat-ayat sifat, selain àyàt al-ahkām. Bentuk tafsirnya adalah bi al-ma'sūr dan bi al-ra'yi. Bentuk penafsirannya tidak lepas dari sumber yang digunakannya, yakni bersumber pada al-Qur'an, hadis, qaul sahābah, ijtihad ulama, syair, dan qirä'at sab'ah. Penafsiran al-Qur'an dengan al-Qur'an (ayat dengan ayat) menjadi dominan dalam penafsirannya. Sedangkan corak penafsirannya adalah corak fikih dan corak bahasa.
\end{abstract}

Kata kunci: Muhammad Amin al-Syinqitịi; Metodologi; Tafsir

\title{
A. Introduction
}

The history of Al-Qur'an interpretation takes place through various stages and over a long period of time so as to reach its form which is the reference of Muslims today. The growth of Al- Qur'an interpretation has begun since the revelation was delivered by the Prophet Muhammad. At that time the interpretation was not developed as it is now, and no one dared to interpret the Al-Qur'an. Then after the death of Prophet Muhammad, the friends began to interpret it. ${ }^{1}$ The Al- Qur'an interpretation from the Companions of the Prophet was well received by the scholars

${ }^{1}$ Subhi al-Ṣālih, Mabāhis fì Ulūm al-Qur'ān (Cet. ke-XVI, Beirut: Dār al-Ilmi Li al-Malāyīn, 1985), h. 411. 
of the tabie, so that groups of commentators appeared in Mecca, Medina, and Iraq. The commentators of this period are an opening for Tabari which is then followed by almost all commentators of the next generation.

During the codification, which independently wrote interpretations as a specific group of knowledge. Among the scholars at that time who wrote it besides alTabarì (d. 310 H), was Ibn Mājah (d. 273 AH), Abū Bakr al-Munzìr al-Naisaburì (d. 318 AH), Ibn Abì Hātim (d. 327 AH), Abu al-Shaykh bin Hibbān (d. 369 AH), alHakim (d. 405 AH), Abu Bakr bin Mardawaih (d. 410). ${ }^{3}$ After that interpretation continues to develop into modern times. One well-known modern figure is Muhammad Abduh and Rasyid Riḍa, Amin al-Khuli, Bintu Syați', including Muhammad Amin al-Syinqiți and other figures.

The development of interpretation can not be separated from the diverse backgrounds of life, education and science of these figures. Like Muhammad Amin al-Syinqiti who was the subject of this discussion, he was an active commentator in the field of education and devoted himself to the government as jugde with a Maliki

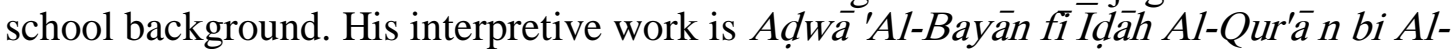
Qur'an consisting of 10 volumes, is his work with his student 'Ațiyyah Muhammad Salim. This study wants to show the interpretive model of interpretive scholars from Syinqit Mauritania, specifically explaining the interpretation methodology, including explaining the systematics, methods, forms, and interpretation patterns in the book.

\section{B. Research Methods}

This research is a type of library research, which is a literature study or research intended to obtain complete information and to determine the actions taken as important steps in scientific activities. ${ }^{4}$ The research approach is an exegetical approach, which is studying the content of the Qur'an through translation or through studies of the Qur'an by existing scholars, then provides a critical and comparative analysis. In other words the interpretation approach, the researchers examine the work of a commentator or more, both critically and comparatively. This interpretation approach is taken to examine the perspective of the interpretation of the Qur'an from the figure of Muhammad Amin al-Syinqiți. ${ }^{5}$

\section{Muhammad Amỉn Al-Syinqītī's Interpretation Methodology}

Interpretation methodology is a scientific study that discusses the procedures and steps of interpretation. ${ }^{6}$ The following will be explained about aspects related to the scope of the interpretation methodology of Muhammad Amin Al-Syinqitīi.

\footnotetext{
${ }^{2}$ Subhi al-Ṣālih, Mabāhis fi Ulūmi al-Qur'ān, h. 412-413.

${ }^{3}$ Manna' Qaț̣ān, Mabāhis fì Ulūm al-Qur'ān (Riyadh: Ma'had al'Āli lil Qaḍā'i, t.t.), h. 427.

${ }^{4}$ P. Joko Subagyo, Metode Penelitian; teori dan Praktek (Jakarta: Rineka cipta, 1991), h. 109.

${ }^{5}$ Abd. Muin Salim, dkk., Metodologi Penelitian Tafsìr Mauḍ̄̄'i (Makassar: Pustaka al-Żikra, 2011), h. 100 .

${ }^{6}$ Ahmad Izzan, Metodologi Ilmu Tafsir (Bandung: Tafakur, t.t.), h. 98
} 


\section{Biography of Muhammad Amin Al-Syinqīiti}

Al-Syinqiți's thoughts are more inclined in the field of fiqh, this is due to his background as a regional judge, his exegetical in his commentary book which is more to discuss the Ahkām verse. In his hometown Mauritania is a Maliki's thought. However, when he moved out to Medina, he was among those who were open mind to knowing other schools of thought. For example while in Medina he met two shaykhs, one of whom was Sheikh Abdul Azìz bin Sālih who gave him knowledge of the book al-Mugni as the basis of the school of thought, and several books of Ibn Taymiyyah as manhäj of faith. from that then he found a school of Imam Ahmad bin Hambal. Including when he taught at the Prophet's Mosque, associating with lay people and specialists, so that he found people with different sects representing the four mazhab and discussed them. So he also mastered the four mazhab, and expanded the study of hadith.

He also has an objective in explaining the truth. ${ }^{8}$ There are several attitudes that show to avoid fanaticism of the mazhab, or the tendency to avoid school subjectivity, namely including the Prophet's hadith in the issue of disagreement among the Imam of the School, then looking for as ar from qaul sahäbah or the opinion of a tafseer scholar, describing analogies with qiyas, also analyzes the meaning of the word in dispute. State the opinions of the Imam Schools and conclude after presenting them, explaining the similarities and differences of opinion among these scholars. He mentions or quotes a certain opinion "hà $\mathrm{kaz}^{\circ}$ a qīla", hā kaz a yaqūlūn. So it can be said that al-Syinqiți really appreciates differences even though he has a different manhajj from other scholars.

a. Life, Educational background and Career

His real name is Muhammad al-Amin, with the nickname $\bar{A} \bar{b} \bar{a}$ (with mad in the letter hamzah and tasydid in the letter $y a$ '). He was born in $1325 \mathrm{H}$ in Tanbah of Kaifa province, Syinqith, a country called Mauritania. ${ }^{9}$ The word Syinqith attached to it is the name of a part of the village of Athor province, the northwest end of Mauritania. ${ }^{10}$ His father's name was Muhammad bin Ahmad Noah bin Muhammad bin Sayyid Ahmad bin al-Mukhtar, from the grandson of al-Thalib Oubek. Namely the grandson of Kuraiz bin al-Muwafi bin Ya'qub bin Jakin al-Abar, grandfather of a

\footnotetext{
${ }^{7}$ Muhammad Amīn al-Syinqị̄ịi, Aḍ̂ā' al-Bayān fì İdāh Al-Qur'ān bi Al-Qur'ān, Juz 1, (Qāhirah: Dār al-Hadis, 2006)h. 20.

${ }^{8}$ Muhammad Amīn al-Syinqīịi, Aḍ̂à' al-Bayān fī İdāh Al-Qur'ān bi Al-Qur'ān, Juz 1, h. 30

${ }^{9}$ General description of the city of Mauritania has a social life that is divided into two, namely Arabic and non-Arabic. The national language is Arabic with the majority of the population being farmers and craftsmen from non-Arab populations, while their descendants are al-Zanuj. The Arab population is divided into two; claimant of knowledge and not claimant of knowledge. Claimers of knowledge are those who usually seek knowledge while trading, while non-prosecutors of knowledge are those who usually trade and attack other tribes. Jakniy Kabilah is a tribe who studied with war skills to maintain honor. Their habits allow guests to stay overnight at their home, and the people around them also give something to please guests, in other words, that their tribe is a friendly tribe and has a noble character. In this area Muhammad Amin Al-Syinqiti was born and enlarged.
}

${ }^{10}$ Muhammad Amīn al-Syinqīịi, Aḍ̂āa al-Bayān fī İdāh Al-Qur'ān bi Al-Qur'ān, Juz 1, h. 12. 
large tribe known as al-Jakniy. According to the Mauritanian poet Muhammad Faal, this tribal passage returns to Humair who is very fluent in their Arabic. ${ }^{1}$ Unfortunately his father died when he was a child, when he was just learning juz 'amma.

At the age of ten years al-Syinqithy had memorized the Qur'an guided by his uncle Abdullah bin Muhammad al-Mukhtar bin Ibrahim bin Ahmad Noah, the uncle of his mother's side. Then he learned the writing of the Ottoman Manuscripts from his uncle Sayyidi Muhammad bin Ahmad bin Muhammad al-Mukhtar, namely At the age of sixteen, besides he also learned tajwid to him with Qiraat Nafi with a history of Warasy through the path of Abu Ya'qub al-Azraq, and Qalun from the history of Abu Nusyaith, and took sanad to the Prophet.

Not only studying qiraat, al-Syinqiți also studied short books about the Malik fiqh, such as rajaz Shaykh Ibn 'Asyir, as well as studying the sciences of Al - Quran, literature, biography and history at his uncle's house, through his uncle, even from his uncle his uncle's wife and children, in other words his uncle's house was his first school.

He is a well-known and competent judge in his field. He is one of the scholars who are called Lajnah Dima $\bar{a} \cdot{ }^{14} \mathrm{He}$ is also a member of the Ulama High Council, an institution under the Fatwa Institute and is the largest scientific institution. His position in the Muslim World League, as a member of the founding assembly. ${ }^{15}$ died in Mecca in $1393 \mathrm{H}$ which coincided on Thursday the 17th of December. He died after performing the pilgrimage and was buried in the Ma'la cemetery. He died after preserving his studied knowledge, having educated thousands of students from high school alumni and the Idarah 'Ammah in Riyad and the Islamic University in Medina. ${ }^{16}$

b. His works

His works composed in his country (Mauritania), all in the form of manuscripts (handwritten), namely:

1) Arabic Names in the form of nuzum (poetry), which he composed before his age was baligh. What he called "Khälis al-Jumān"

2) Poetry regarding the branches of the Malik school, that is, the specific contents of the sale and purchase agreement and pledge, whose number of poetry reaches thousands of stanzas.

\footnotetext{
${ }^{11}$ Muhammad Amīn al-Syinqị̣̂ị, Aḍ̛wā al-Bayān fì İdāh Al-Qur'ān bi Al-Qur'ān, h. Juz 1, 11-
} 12.

${ }^{12}$ Muhammad Amīn al-Syinqị̦īi, Aḍ̛̂ā' al-Bayān fī İdāh Al-Qur'ān bi Al-Qur'ān, Juz 1, h. 13.

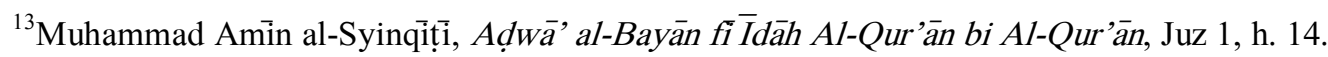

${ }^{14}$ Muhammad Amīn al-Syinqīịì, Aḍ̛wà' al-Bayān fí İdāh Al-Qur'ān bi Al-Qur'ān, Juz 1, h. 19.

${ }^{15}$ Muhammad al-Amīn al-Syinqīịi, Aḍ̛wā' al-Bayān fì İdāh Al-Qur'ān bi Al-Qur'ān, Juz 1, h. 25-26.

${ }^{16}$ Muhammad Amīn al-Syinqịị̂i, Aḍ̛wāu al-Bayān fī İdāhi Al-Qur'ān bi Al-Qur'ān, Juz 1, h. 67

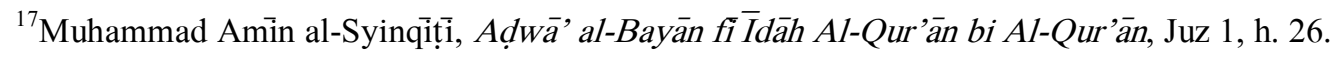


3) Alfiah (a thousand verses of poetry) about mantiq.

4) Nuzum about farāiḍ

His books in Saudi Arabia include: ${ }^{18}$

1) Javanese Man'ū jawaz al-Majāz fi al-Munazzal li al-Ta'abbud wa al-I'jāz, this book contains about the cancellation of the application of majaz in asthma verses and their nature and sufficiency according to the nature . Then add meaning afterward in "Adab al-Bahat wa al-Munaz direction".

2) Daf'u Ihàm al-Idtirāb 'an Ayi al-Kitāb, this book contains themes that look like contradictions in the whole Qur'an.

3) Mużākarah al-Ushūl 'alā Raud ah al-Nazir, contains about his sharah about the ushul rules of the Hambali school, Maliki, and Shafi'i. This book is a textbook in the Sharia faculty and the Da'wah faculty.

4) Adāb al-Bahs wa al-Munāz direction, this book contains his explanation of research ethics; namely the presentation of problems, the explanation of the proposition, and so on. This book is also a dictate at the university, consisting of two volumes.

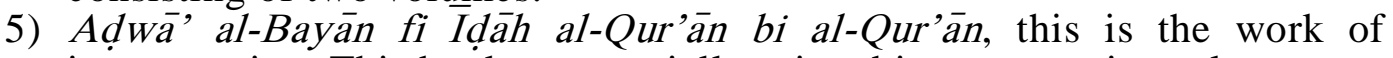
interpretation. This book was partially printed in seven major volumes, up to the letter al-Mujāilah. Then continued by his students 'Ațiyah Muhammad Sālim until volume 10.

In addition to some of the works of the book, there are some of the results of his lectures and lectures that have their own themes, and have been printed, namely: ${ }^{19}$

1) Ayät al-Sifät, about research into determining the attributes of Allah.

2) Hikmah al-Tasyri ', which is about a number of Tasyri's wisdom in most of the laws

3) Al-Matal al-'Ulyā, contains an explanation of the standard measures in the creed, tasyri 'and morals.

4) Al-Masallih al-Mursalah, his explanation of the terms of use, namely excessive and indiscriminate attitudes.

5) Haula Syubhah al-Raqiq, erases the mistake of the claim that Islam enslaves free people.

6) 'Ala (al-yauma akmaltu lakum dinakum wa atmamtu alaikum ni'matīi), this lecture he delivered in front of the 5th King Muhammad during a visit to Medina.

\section{Systematic Interpretation of Muhammad Amīn Al-Syinqītīi}

While the systematic writing of the book, can be seen as follows:

a. Orderly verse and orderly letter, that is from surah al-Fätihah to surah al-

Nās. The verses that are interpreted are not all written in one letter of the


$27-28$.

${ }^{19}$ Muhammad Amīn al-Syinqị̂ị, Aḍ̂āu al-Bayān fì İāhi Al-Qur'ān bi Al-Qur'ān, Juz 1. h. 28
} 
Qur'an, and one letter does not always start from the first verse. The verse interpreted is not always written in full from the beginning to the end of the verse.

b. Writing the name of the letter al-Qur'an at the beginning of the discussion, which is written in the middle like the initial title. Can be exemplified when he interprets verses from surah al-Fatihah, he writes in the middle at the beginning of writing the name of the letter al-Qur'an, or when he interprets verses from surah al-Máidah, he also writes the names of surahs at the beginning, and so on in each volume of his work. Write the bismillahirrahmanirrahīm after writing the name of letter of the Qur'an. He did not write the title or subtitles to begin the discussion, but if someone wants to see or search for specific topics, it can be seen in the table of contents that is placed at the end of each volume, not directly the topic but only the letter and verse are included.

c. Write the word قوله تعالي before mentioning the verses of the Qur'an to be explained, and write them in the middle, each verse that it interprets, in every volume of the book. After that he explained the purpose of the verse by mentioning other verses (bayānuh al-Qur'ān bi al-Qur'ann).

d. Include the word tanbih (note) for verses which according to him need a deeper discussion of the verse that is interpreted. What he meant was to give emphasis or conclusions and affirmations, in addition to the tanbih not always in the form of his own opinion, but also he quoted from a number of opinions. An example of tanbihh in its interpretation is as follows:

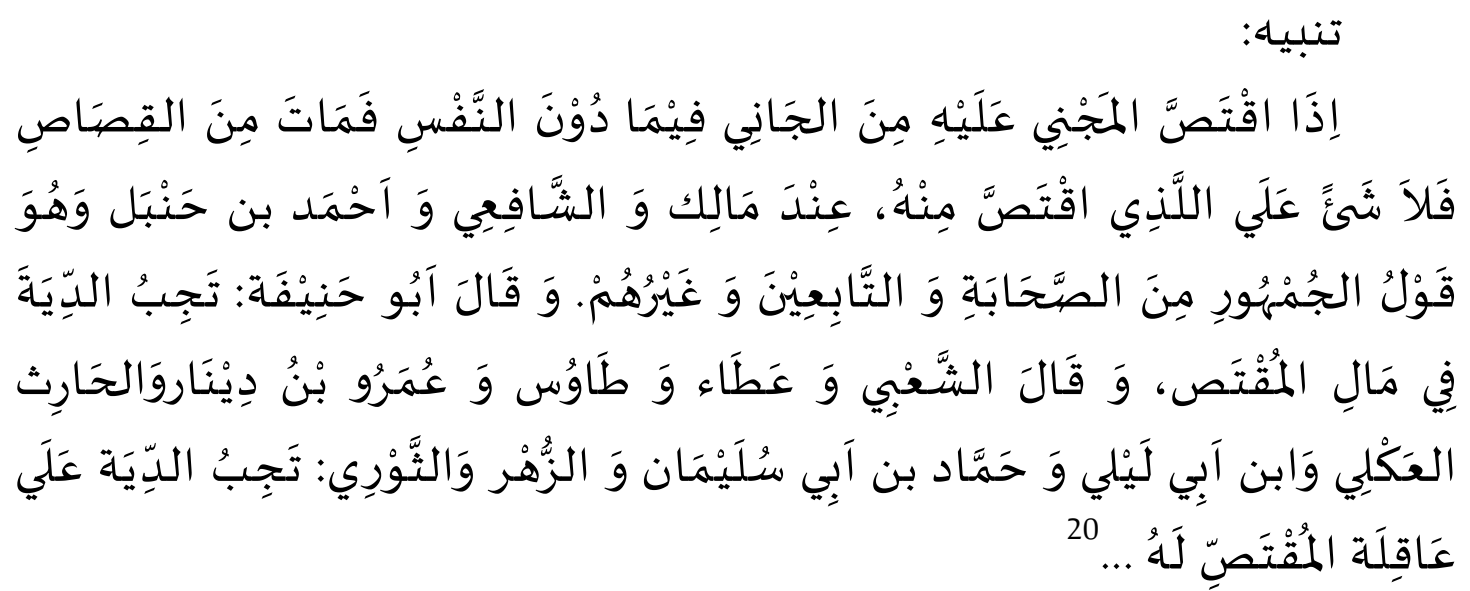

Meaning:

"Note: If a criminal victim commits qisas to a criminal in a matter that does not take a life, then the culprit dies because of qisas, then those who carry out the qisas right are not charged according to Malik, Syafi'i and Ahmad bin Hambal. This opinion is also the opinion of the majority of friends, tabi'in and others. Abu Hanifah said the diyat must be paid from the property of the claimant qisas. Meanwhile, according to al-Sya'bi,

${ }^{20}$ Muhammad Amīn Al-Syinqīị̂i, Aḍ̛wāu Al-Bayān fî̀ I̦̣āhi Al-Qur'ān bi Al-Qur'ān, Juz 2 (Qahirah: Dār al-Hadis, 2006), h. 58-59. 
Atà', Tầus, Amr bin Dinar, al-Haris al- 'Ukli, Ibn Abi Laila, Hammad bin Abi Sulaiman, al-Zuhri, and al-Sauri that diyat must be paid by the families of claimants qișas...

Tanbih written by al-Syinqit $\bar{i}$ in this book aims to provide reinforcement and affirmation to its interpretation, provide explanation and enlightenment when he lists some opinions of scholars about something, especially its relation to problems agreed upon and disputed among scholars. As exemplified by the tanbīh about its interpretation of Surah al-Mäidah/ 5: 32.

e. Including the masāil, he specified the term masail as a presentation of problems relating to differences of opinion among scholars regarding the law of a verse in question, this inclusion is only on ayät al-ahkäm. For example, when he interpreted Surah al-Haj/ 22: 78. He explained the problem of the differences in scholars about the time of the shock; did the shock occur after humans were compared from their graves, when they were raised to the apocalypse? Or the shock is like the shock of the earth before man comes out of his grave. He then explained a group of scholars said that this shock would occur at the end of the world and the beginning of the Day of Judgment. He put forward that opinion from the opinions of Alqalamah, al-Sya'bi, Ibrahim, Ubaid bin Umari, and Ibn Juraij. He said that this opinion was supported by logic, and there was no argument to strengthen it. On the contrary, the arguments contradict it, namely the group's argument which says and originates from the hadith ma'rüf which is narrated, but this hadith is da'if and may not be used as an argument. Furthermore al-Syinqiți also explained the interpretation of al-Tabari that when explaining the arguments people say that the shock occurred at the end of the world before big is the problem of debate between interpreter scholars and fiqh scholars in every verse that they interpret. ${ }^{21}$

\section{Interpretation Methods}

Al-Qur'an's method of interpretation according to Abdul Djalal is a way of interpreting the verses of the Qur'an in an orderly manner, using the sources of interpretation, the steps in the description of interpretation, and the aims and objectives of its interpretation. ${ }^{22}$ Al-Syinqiti followed the model of several earlier commentators and became one of the sources of his interpretation, such as Ibn Jarir al-Tabari $^{23}$, Zamakhsyari ${ }^{24}$, and al-Qurtubi ${ }^{25}$.

${ }^{21}$ Muhammad Amīn Al-Syinqīțì, Adwà', Al-Bayān fì Ị̇āh al-Qur'ān bi al-Qur'ān, Juz 5 (Qahirah: Dār al-Hadis, 2006), h. 469-470.

${ }^{22}$ Abdul Djalal HA, Urgensi Studi Tafsir Yang Mutakhir (Surabaya: IAIN Sunan Ampel, 1987), h. 20.

${ }^{23}$ Tabari has the full name Muhammad Ibn Jarir Ibn Yazid Ibn Khalid al-T abari, besides it is called Muhammad Ibn Jarir Ibn Yazid Ibn Kasir Ibn Ghalib al-Talib, al-Tabari was born in Tabaristan in $224 \mathrm{AH}$ and lived in Baghdad until his death, Tabari died in 310 H / 923 AD. Srifariyati, "Manhaj Tafsir Jami’ Al-Bayan Karya Ibnu Jarir Al-Ṭabari”, Madaniyah 2, vol. 7 (2017), h. 321. M. Rusydi Khalid, Manāhij Al-Mufassirin; Mengkaji Metode Para Mufassir (Jakarta: Mazhab Ciputat, 2016), h. 1 . 
Each exegete has a tendency to interpret the verses of the Qur'an. Like alTabari uses the method of tahlili in interpreting verses of the Koran as a whole based on the composition of the Manuscripts, and disliking bi al-ra'yi, presenting history, aśar with his sanad, respecting ijma', holding on in qira'at, nahwu and in Arabic poetry. ${ }^{26}$

Then Zamakhsyari with his interpretation of al-Kassyäf, his interpretation analysis uses the method of tahlili in the form of bi al-ra'yij, quoting Rusydi Khalid's opinion that the data source he uses more ratios which are often referred to as the tafsir bi al-ijtihāadi or interpretation of bi al-dirāyah. Not that only bi al-ra' $\bar{y}$, but also use bi al-ma'sür, it's just more dominant bi al-ra'yi. ${ }^{27}$

Besides al-Qurtubi with the method of tahlili and is an interpretation of bi alma'sür. Namely outlining verses coherently in accordance with the Manuscript. But he also uses the muqärin method, because many compare the opinions of various Muslim scholars and comment or combine those opinions. ${ }^{28}$ The commentators are some of the figures that al-Syinqiti $\bar{i}$ references in interpreting verses of the Qur'an. Perhaps as its predecessor, it follows the model of interpretations which uses the interpretation of bi al-ma'sur , making the Qur'an as the main source of its interpretation. Regarding this, it can be seen from the description of its interpretation in the previous discussion. He prefers to applyed the tahli $1 i$ method in interpreting the Qur'an, this can be seen in each ahkam verse which he explains in analytical detail.

While the interpretation method used by al-Syinqiți is the method of tahlili, ijmāti. For an explanation, it can be seen as follows:

a. For example in interpreting the tahlili method on QS Al-Haj / 22: 27; ${ }^{29}$

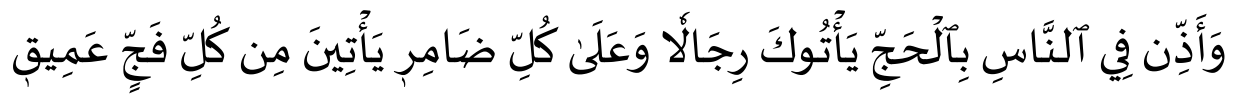

Translation:

"And call on people to do the pilgrimage, surely they will come to you on foot, and ride every thin camel, they come from all directions far away."

\footnotetext{
${ }^{24}$ His name is Abu al-Qā sim Mahmud bin Umar al-Khawarizmi al-Zamakhsyari, Born on 27
} Rajab $467 \mathrm{H} / 1075 \mathrm{AD}$ in the small village of Zamakhsyar located in the Khawarizmi region. A $1 \mathrm{i}$ Iyāzi, Al-Tafsīir wa Al-Mufassirūn Hayātuhum wa Manhajuhum, h. 574. Compare with M. Rusydi Khalid, Manāhij Al-Mufassirin; Mengkaji Metode Para Mufassir, h. 30.

${ }^{25}$ His full name is al Imam Abū Abdillāh Muhammad ibn Ahmad ibn Abū Bakr ibn Farh alAnș ori al-Khazraji al-Andalusi al-Qurtubi al-Mufassir, Al-Qurt yam is the name of an area in Andalusia, namely Cordoba, where it is was born. Muhammad Husain al-Zahabi, Al-Tafsir wa AlMufassirin, Jilid 2 (Kairo: Darul Hadis, 2005), h. 401.

\footnotetext{
${ }^{26}$ M. Rusydi Khalid, Manāhij Al-Mufassirin; Mengkaji Metode Para Mufassir, h. 15.

${ }^{27}$ M. Rusydi Khalid, Manāhij Al-Mufassirin; Mengkaji Metode Para Mufassir, h. 34.

${ }^{28}$ M. Rusydi Khalid, Manāhij Mufassirīn; Mengkaji Metode Para Mufassir, h. 56.

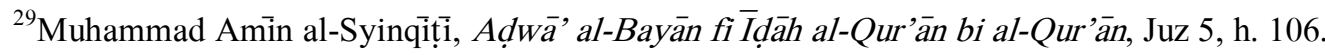


The analysis of tahlili he uses is as follows: first he analyzes in a language about lafz aż and that is al-I'läm (notice) he exemplifies from QS al-Taubah / 9: 3. Lafz al-Haj according to language is headed, and often visits and commutes. to support this opinion, he said that the Arabs said hajja banū fulān fulānan (banu fulan came to fulan) if they went to him, often visited him and went back and forth to him. He gave an example of the words of al-Makhbal al-Sa'di which means: "Do you not know, O Umm As'ad, that doubt of grace (Allah) has plunged me into the greatest sin, while I witnessed useless men in various beginning (season) to perform the pilgrimage with the Zabriqan turban who were given Za'faran. "According to the poet's utterance" Yahujjuna" (performing the pilgrimage), the intention is that they often go to him, come to him, and commute to him. The word "Sibba" is a turban, the purpose of the poet from the existence of those who visit their turban is, they carry out the pilgrimage. They performed it with a turban.

Then the word rija lan according to him is the plural of the word rajil which is a person who walks on both feet. Damir is a camel and the like that is mażhul, which is tired from traveling. The word ya'tina (coming) is al-dawamir (camels), which is expressed by damir kulli. Because the word kulli is a general word that includes many camels. The word fajj is the way, which is plural in fijaj, it is based on QS al-Anbiyā'/ 21: 31 "waja'alna fí hà fijajan subulan la'allahum yahtadūn" and the poem "iz a alkhailu jā at min fijajin 'amiqatin ". Word 'Amiq itself is often used for long distance down (in). The Arabs say bi'run 'amiqun (deep well), which is far at the bottom.

He then included the opinions of some scholars regarding the verses of this verse, namely according to the majority of scholars that the bible was addressed to Prophet Ibrahim, as the storyline is clear. The opinion of al-Qurtubi who agrees with al-Hasan's opinion says that the Bible verse is addressed to the Prophet Muhammad and the Prophet Ibrahim. The majority of scholars he intended such as Ibn Kasir who narrated the history of Ibn Abbas, Mujahid, Ikrimah, Sa'id bin Jubair and other salaf scholars, were also told by Ibn Jarir and Ibn Hatim with a long editor. ${ }^{32}$

Lafz ya'tüka make it in jazam because it became the answer amr (command). According to the Arabic expert lafz ya'tūka was guaranteed by the conditions saved but indicated by lafz amr. Allah uses ya'tüka because those who are called will face those who call, even though they actually come to perform the pilgrimage. This is due to Ibrahim's call is a call to perform the pilgrimage. It means they will come to you while fulfilling your call and going to Baitullah, as you have called them to do. ${ }^{33}$

According to him, when referring to al-Hasan's opinion which states that this verse is addressed to the Holy Prophet. then this verse is an argument that shows the obligation of Hajj. In the majority of scholars, the obligation of Hajj to the Ummah is also indicated by this verse, on the basis that the Shari'a for the people before us is Shari'a for us too. In addition there are a number of verses according to al-Syinqiti which show that the obligation mentioned by Ibrahim's oral also occurs in the oral of

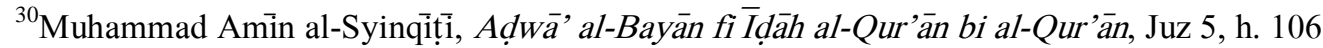

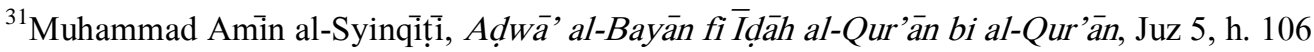

${ }^{32}$ Muhammad Amin al-Syinqị̣̂i, Aḍ̂ā' al-Bayān fi Î̦̣̄h al-Qur'ān bi al-Qur'ān, Juz 5,h. 107.

${ }^{33}$ Muhammad Amīn al-Syinqīị̂i, Aḍ̂ā' al-Bayān fi Ị̇āh al-Qur'ān bi al-Qur'ān, Juz 5, h. 107
} 
the Prophet Muhammad. there are QS Āli Imrān/ 3: 97, QS al-Baqarah/ 2: 196, QS alBaqarah/ 2: 158 .

Then he explained at length about the opinion of some scholars about the verse "ya'tūk rijālan wa'alä kulli ḍamirin", which is about hajj by driving or walking. Regarding this, he explained his interpretation with a special discussion of the long jurisprudence rules on hajj. Citing the opinions of the scholars of hadith, mentioning the position of the hadith, including the opinion of the Imam of the School. ${ }^{35}$ Provide notes after describing the opinions of the scholars. In terms of the interpretation of QS al-Haj/ 22: 27, his presentation on this is very long.

b. Examples of interpretation with the method ijmatii on the interpretation is in QS al-Māidah / 5: 51,

Allah SWT has mentioned in this verse that the Jews and Christians some of them are helpers for some others. But in another verse it is explained that the help of some of them to others is false help, not pure because it does not rely on the right basis, namely Islam. So the animosity and hatred among Christians is permanent until the Day of Judgment, as His words in QS al-Māidah/ 5: 14:

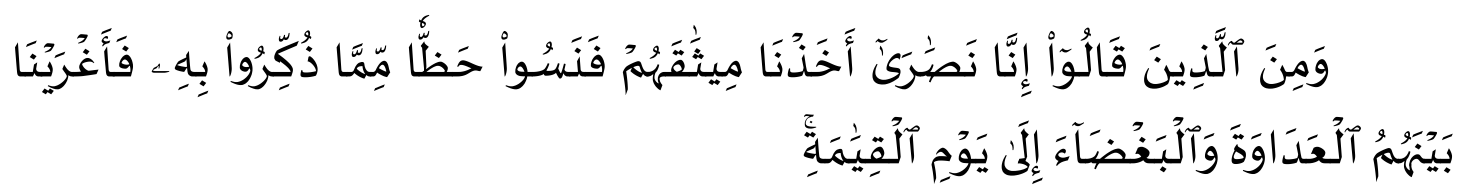

Translation:

"And among those who say: "Truly we are Christians", some of us have taken their covenant, but they (deliberately) forget some of what they have been warned with; then We arouse between them hostility and hatred until the Day of Judgment."

In addition he explained the same thing about Jews with QS al-Māidah/ 5: 64:

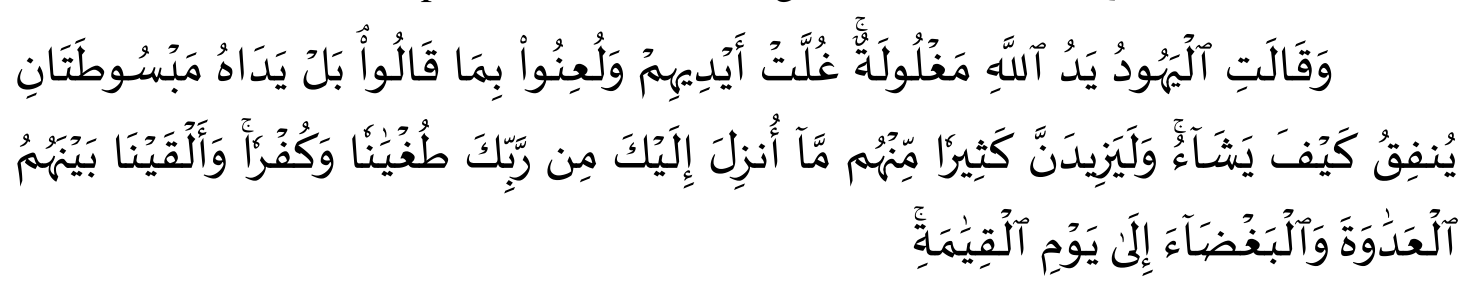

Translation:

"The Jews say: "The hand of God is shackled", in fact it was their hands which were bound and they were cursed because of what they said. (Not so), but both hands are open; He spend as He wills. And the Qur'an which was

\footnotetext{
${ }^{34}$ Muhammad Amin al-Syinqīịi, Aḍ̂ā' al-Bayān fi Ị̇āh al-Qur'ān bi al-Qur'ān, Juz 5, h. 110

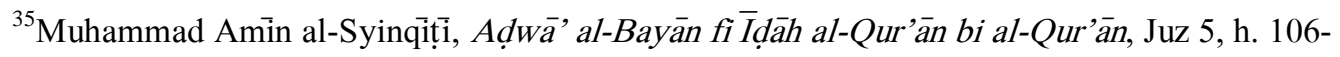

113.

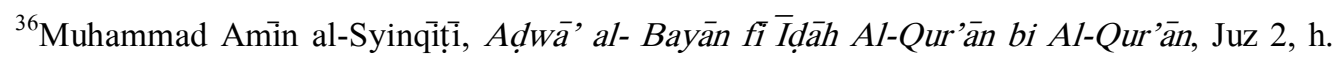


revealed to you from your Lord will truly increase wickedness and disbelief for most of them. And We have caused hostility and hatred between them until the Day of Judgment."

In zähir that the verse is addressed to the Jews towards their fellow man, as seen from the context. In contrast to those who say that the verse is intended for Jews and Christians. According to him God explained the lack of understanding among the Jews, because they were not people who wanted to think, as contained in QS alHasyr/ 59: 14;

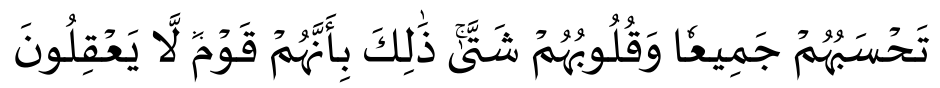

Translation:

"You think they are united, their hearts are divided. That is because they truly are a people who do not understand."

Note: some scholars set the word of God "some of them help others," that Jews and Christians pass down one another. Others refute this by saying the purpose of the verse is special Jewish help to Jews, specifically Christians to Christians. Based on this provision, there is no proof in the verse about mutual inheritance between Jews and Christians.

These are some examples of his interpretation methods, when interpreting verses related to legal verses, the analysis is very long with the analysis of the methods of tahlili and muqärin. In another verse he analyzes the verse in terms of language and quotes some of his predecessor's opinions such as al-Qurtubi and others, making notes for his conclusions on the verse he wants to mean, as well as his interpretation of the QS. Al-Maidah/ 5: 6, and other verses, he also included the opinions of the mufasir, fuqaha which he explained compared to what he compiled called as the masaill, and gave conclusions. This model can also be said as a muqärin method at once, this can be noted al-Syinqithy including the opinions of some scholars such as Zamakhsyari, al-Qurtubi, al-Ṭabari, then looking for differences from giving conclusions with his arguments, so also with the hadith. This method is seen from its interpretation of $\bar{a} y \bar{a} t$ al-ahk $\bar{a} m$. The method of tahtili is a method of analysis that seeks to explain the meaning of the verses of the Koran with various aspects, namely based on the order of verses and letters, highlighting the meaning and content of lafz -lafz, the verses of the verses, because nuzul, the Prophet's hadith, and the opinions of friends and other scholars. ${ }^{38}$ The ijma $\overline{l i}$ method, as exemplified, states that the interpretation of verses other than the law tends to be short, only explaining the meaning of the word in a literal way, also interpreting with other verses related to the verse, such as the interpretation of the QS al- Maidah 5/51.

If you look at the analysis of al-Syinqithy in interpreting the verses of $\mathrm{Al}$ Quran from the term illustrates that he followed in the footsteps of the earlier commentators that he quoted in his writings, which even he also included israiliyat as 75

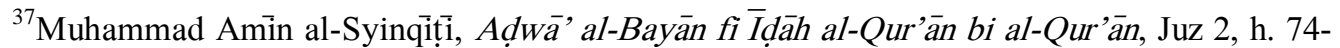

${ }^{38}$ Badri Khaeruman, Sejarah Perkembangan Tafsir Al-Qur'an (Bandung: Pustaka Setia, 2004), h. 94. Mardan, Al-Qur'an Sebuah Pengantar (Jakarta: Mazhab Ciputat, 2015), h. 332. 
a source of interpretation. ${ }^{39}$ Reference figures such as al-Tabari, al-Qurțubi, Zamakhsyari and others. It can be said that in interpreting the Qur'an, attention is paid to all aspects contained in the verse interpreted by several methods of interpretation; the tahlili, ijma $\overline{l i}$ methods. Citing Baqir al-Șadr that explaining the interpretation from comprehensively is a partial thing in the verses interpreted by mufasir.

\section{Form of Interpretation}

According to Arham Junaidi, the analytical interpretation method is an interpretation that describes munassabah between verses and surah, asb $\bar{a} b$ al-nuz $\bar{u}$, identifies the meaning of words, and explains the meaning and purpose of syara 'contained in the verse, so that in the application of this analytical method have there is a model or in the form of interpretation of bi al-ma'sür and there is a bi al-ra'yi. As it is known that there are two models in the interpretation of the verses of the Qur'an, namely the interpretation of bi al-ma'siur and the interpretation of bi al-ra'yi. The interpretation model of bi al-ma'sur is a model that uses the source of the Koran and authentic history, namely interpreting the Koran with the Koran (verse by verse), interpreting the Koran with the hadith, and qaul sahabah. There is another term from the interpretation of bi al-ma'siur which is the interpretation of al-naqli. Where as tafsir bi al-naqli is the antonym of tafsir bi al-aqli (bi al-ra'yi). ${ }^{4}$

Tafsir bi al-ra'yi (ratio) is ijtihad in understanding the Qur'an within the limits of knowledge about Arabic language by fulfilling the obligations of a mufasir, both scientific and moral requirements. Mastering science, especially science nahwu, sharaf isytiqaq, balaghah, qira'at, ushuluddin, ushul fiqh, asbāb al-nuz $\bar{u} l$, nasikh mansukh, hadith, while morals are related to kibr, lust, bid'ah, love the world and likes to $\sin$. 42

The interpretation that has been done by al-Syinqithy is in the form of bi al$m a ' s \bar{u} r$ and $b i$ al-ra'yi, but the tendency of its interpretation is bi-al-ma'sur interpretation. To see this can be noted from several examples of interpretation in QS al-Anbiyā'/21: 92-93. As the conditions above can be categorized that the steps taken in finding the meaning of the verse in accordance with the standard conditions that are commonly done other commentator. The interpretation of $b i a l-r a^{\prime} y i$ is seen when he interprets àya $\bar{t}$ al-ahkām.

\section{Interpretation style}

The style of interpretation of Muhammad Amin al-Syinqiți is fiqh and lughawi. Manna' Qatțan mentions several fiqh-style commentaries, including Ahkām Al-Qur'ān by al-Jașsas, Ahkām Al-Qur'an by al-Kiya' al-Harras, Ahkām Al-Qur'ān by Ibn' Arabi, Jami' Li Ahkām Al-Qur'an by al-Qurțubi, Al-Iklil fí Istinbāt al-Tanzi ${ }^{-1}$ by al-Suyūtị, al-Tafsìr Al-Ahmadiyah fi Bayāni Ayat Al-Shariah by Mulla Geon, Tafsir

\footnotetext{
${ }^{39}$ See the interpretation of QS al-Anbiyā '/ 21: 70 in the previous discussion.

${ }^{40}$ Muhammad Baqir al-Ṣadr, Madrasah Al-Qur'aniyah, terj. Hidayaturakhman (Jakarta: Risalah Masa, 1992), h. 18.

${ }^{41}$ Afrizal Nur, Khazanah dan Kewibawaan Tafsir bi Al-Ma’'sur (Cet.ke-I; Riau: Fakultas UIN SUSKA RIU, 2015), h. 44.

${ }^{42}$ Yūsūf Qaraḍ̄āìi, Kaifa Nata'amalu Ma'a Al-Qur'à Al- 'Ażìm, terj. Abdul Hayy al-Kattani (Cet.1; Jakarta: Gema Insani Press, 1999), h. 297.
} 
$\overline{A y a} \bar{t}$ Al-Ahkām by Shaykh Muhammad al-Sayis, Tafsī $r \bar{A} \bar{a} t$ al-Ahkām by Manna' Qattan itself, including Aḍ̂ā' Al-Bayān fî̀ Ị̇āh Al-Qur'ān bi Al-Qur'ān by alSyinqithy.

Although in some other verses it is not as detailed as the legal verses. This is probably what was mentioned by Manna' Qattan in his book which mentioned the work of al-Syinqiti is a category of interpretation of ahkam, interpretation of figh. ${ }^{44}$ Because every discussion about the verses of the law, he always explained it with lengthy details related to the issues that were disputed among fiqh scholars.

As citing the opinion of Manna' Qattan, the interpretation of al-Syinqiti appears in its interpretation of the verses of law such as the interpretation of QS AlMaidah/ 5: 6, he discusses the verse and outlines the fiqh discussion about the tayamum verse from pages 27 to $40 .{ }^{45}$ Discussion on surah al-Haj about hajj even up to 500 (5-525) pages, specifically in QS al-Haj/ 22: 27 about 42-299 pages. And so is the interpretation of other legal verses. different from verses other than àyat al-ahk $\bar{a}$ $m$, short and tend to only explain the Qur'an with the Qur'an, sometimes only in terms of language or qiraat, without lengthy analysis.

The other style is lughawi interpretation style, that al-Syinqiti also sees lughawi sides in its interpretation. Exemplified in QS. Al-Takwï/ 81: 17. Ie several meanings of the word 'as'asa, there are two meanings namely iqbāl al-lail (coming of the night) and idbār al-lail (leaving at night). He further emphasized that the meaning of the word 'as'asa is adbara (departure of the night) in accordance with the QS. AlMudașsir/ 74: 33-34: "wa al-lail iż adbara wa al-subhi iz a asfara". In al-Qur'an often use oaths by using the word al-lail (night time) and using the word fajr (dawn), which is contained in the QS. Al-Lail / 92: 1-2, QS. Al-Syams / 91: 3-4, QS. Al-Duhā / 93: $1-2$, as well as other verses. In this case, trying to take on the meaning that is used more often according to him is more important.

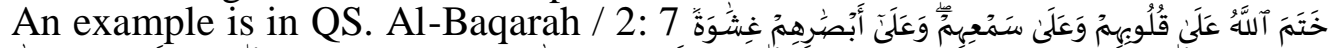

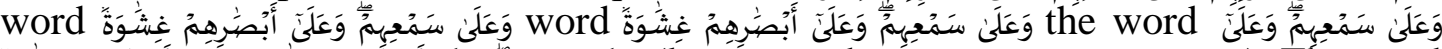

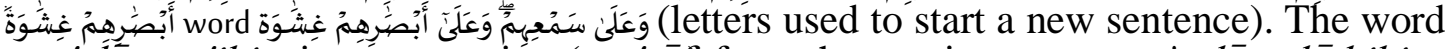
wa 'ala sam'ihim is a connection (ma'tüf) from the previous sentence' alà qulü bihim, while the word wa 'alā abshā rihim ghisyā wah is the beginning of a new sentence (istifnäf) which consists of mubtada' (subject) and khabar (predicate). So the meaning that is locked dead is their hearts and hearing, while what is covered is only their vision. ${ }^{47}$

While the explanation of the meaning of zahir when it is found that the arrangement of the language is not the actual meaning desired, because based on other verses in the Qur'an the actual meaning desired is another meaning different from its zahir. Example of QS. Al-Baqarah / 2: 229 "talaq (which can be referenced) twice", the meaning of zahir that can be captured is that all types of divorce are

${ }^{43}$ Manna' Qaț̣an, Mabāhis fì Ulūm Al-Qur'ān, h. 468.

${ }^{44}$ Manna' Qatțan, Mabāhis fī ulūm Al-Qur'ān, h. 468.

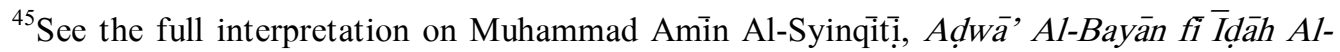
Qur'ān bi Al-Qur'ān, Juz 2, h. 27-41.

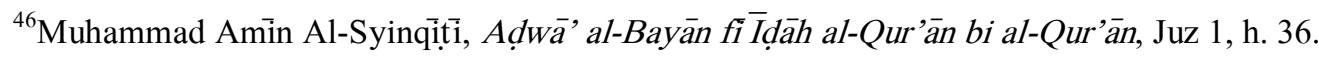

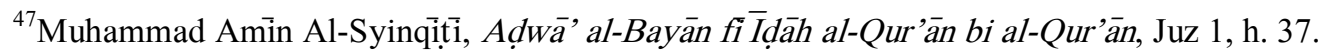


limited only twice, then he explains it in the QS. Al-Baqarah / 2: 230 namely: فَإِن طَّقَََّّا

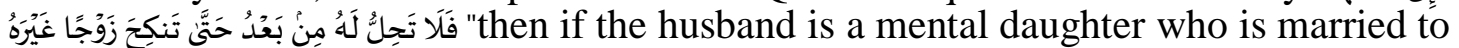
the other, after he is married to the second, then the female husband is the other, after he is married to the other woman, then the second is her husband, then the second is her daughter. ${ }^{48}$

\section{Sources of Interpretation}

Sources of interpretation used by al-Syinqiți in the book of $A d w_{\bar{a}}^{\prime}$ alBayān there are several sources of interpretation, including: sources from the Qur'an itself, the Prophet's traditions, poems, poems, opinions of the commentators of interpretation, this he quoted a lot from the books of commentaries or hadith by scholars such as al-Qurtubi ${ }^{49}$, Abu Ja'far ibn Jarir al-Tabari, al-Zamakhsyari ${ }^{50}$; to quote Zamakhsyar's opinion, he only takes an interpretation of the language side. He also noticed the qiraat in its interpretation in several verses of the Qur'an.

a. Al-Qur'an

The source of its interpretation with al-Qur'an can be seen in the interpretation of al-Syinqiti in every verse of the surah that is interpreted to make al-Qur'an as its main source, the naming of the interpretation book itself provides an explanation. Exemplified in his interpretation of QS al-Maidah / 5: 51. He gave an explanation of the verse with QS al-Māidah/ 5: 80, QS al-Mumtahanah/ 60: 13, QS Āli Imrān / 3: 28. In his interpretation he concluded that zăhir verses are understood that if whoever leaves matters to unbelievers intentionally, voluntarily and likes them, in fact he has become infidels like them. ${ }^{51}$

\section{b. Prophet's Hadith}

The Prophet's Hadith as a source of interpretation, al-Syinqiti paid attention to the traditions that he quoted, wrote the hadith books he cited in footnotes, complete from various hadith books with the same theme. And explain the position of these traditions, especially when interpreting the verses of law, which relate to the rules of fiqh. For example when he interprets QS al-Nisā'/ 4: 101-102. In this context, he listed several traditions; Muslim Imam in his Sahih, Abu Daud, Nasa'i, and Ibn Majah have narrated from Abu 'Awamah al-Waḍ̣ah bin Abdullah al-Yasykari, Imam Muslim added another narrator namely Ayyub bin' A'iz, both of whom narrated from Bukair bin al-Akhnas from Mujahid from Abdullah bin Abbas that he said "Allah has

\footnotetext{
${ }^{48}$ Muhammad Amīn Al-Syinqīịi, Aḍ̂ā' al-Bayān fī Ị̇āhi al-Qur'ān bi al-Qur’ān, Juz 1, h. 40.

${ }^{49}$ One example he cited al-Qurtubi when interpreting QS al-Anbiya QS / 21: 87-88, which is about lafz mughạdiban, that the meaning of lafz is "(Jonah) angry because of his God". For example gadabtu laka (I'm angry because of You), meaning I'm angry for you. A believer will usually be angry because of Allah when there is disobedience. The correct meaning of lafz mughạdiban is the meaning that is in accordance with the interpretation (that Jonah) is angry with his people because of his God, because of their kufr and disobedience to their God.

${ }^{50} \mathrm{He}$ quoted the opinion of Zamakhsyar 'one of which can be seen when he interpreted QS alAnbiyā/21: 92-93.

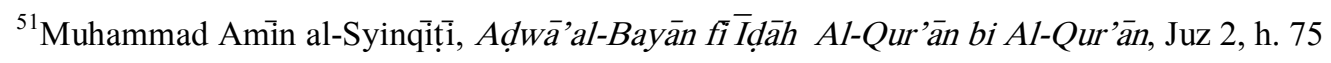


obliged prayer through the tongue of your Prophet, Muhammad PBUH. (with provisions) four rak'ats in a state of not traveling, and one rak'ah in a state of fear. As the Prophet always prayed (sunnah) before and after the obligatory prayer when not traveling. The same hadith has also been narrated by Ibn Majah from Usamah bin Zaid from Tawus. This hadis has been narrated from Ibn Abbas. This Hadith does not contradict the hadith narrated by Aisha.

Al-Syinqiti also explained the opinions of the scholars regarding the hadith of Ibn Abbas and Aisha: 1) According to al-Qadi Abu Bakr ibn al-'Arabi al-Maliki in his book al-Qabas, the hadith is contrary to the ijma 'ulama, according to him "the scholars have said" based on ijma ', this hadith is not acceptable. 2) the hadith is a mudtarib (there is confusion in the eyes). Because Ibn Ajlan narrated from Salih ibn Kaisan from Urwah from Aisha that he said: "The Messenger of Allah. has required the prayers (as much as) two rakas'. "While al-Auza'i has narrated from Ibn Syihab of Urwah from Ayesha that he said," Allah has obliged prayers to the Messenger of Allah (as many as) two rakas'at ". In their opinion this is id t iräb. 3) the hadith must not be understood solely based on the meaning of the end. Because, the maghrib prayer and the dawn prayer are two prayers that do not increase the number of rak'ahs and are also not reduced. 4) This Hadith is a hadith of Aisha which is categorized as a hadith maqt $\bar{u}$ ' (its sanad only reaches friends) and not a marfu hadith, (its sanad reaches the Messenger of Allah). 5) Imam Haramain said "if the hadith is indeed true of the Messenger of Allah, it will surely be reported mut mutually." 53

After he explained the various opinions about the hadith, al-Syinqiți gave muqayyadah by arguing that all the rebuttal related to the Hadith was a weak rebuttal. One example relates to the assumption that the hadith is mudtarib, according to him the hadith has no ambiguity at all. Because basically the meaning of the phrase "Allah has made it compulsory" with the phrase "The Messenger has made it compulsory" is the same. This is not because Allah is Musyarri' (Zat who has prescribed a law), while the Messenger of Allah is a Mubayyin (the person who explains the law). If it is said that the Messenger of Allah has obliged a thing, then the intention is that the Messenger of Allah has conveyed it from Allah. Thus that the expression is not

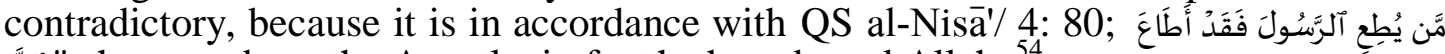
آلسََّ "whoever obeys the Apostle, in fact he has obeyed Allah.

Then the rebuttal is also about the assumption that the hadith is not a marfu hadith. According to him the determination of the number of rak'ahs was not something that could be based on human opinion. The hadith must be punished as a marfu hadith. If the assumption is accepted that Ayesha is not present at the time the prayer was required, then it was likely that Aisha had heard that from the Prophet. while living with the Prophet. If never heard of it from the Prophet. Directly, then that in fact such traditions include the traditions of mursal șahabi (the sanad is interrupted

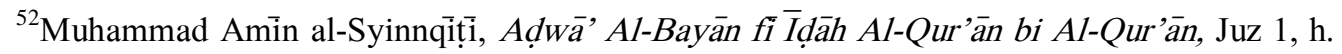
257-258.

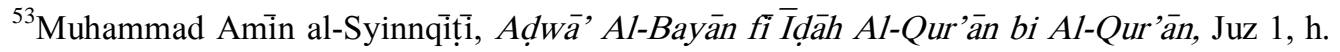
258-259. 259.

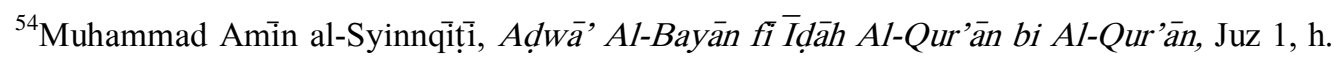


at the level of friends), even though the traditions of mursal șahabi are punished as the traditions of mausul (continuous sanad).

As it is, it can be said that al-Syinqiți in making the hadith as a source of interpretation, becomes his reference in describing his opinion very concerned with the sanad, matan, and position of the hadith. Both the hadith is authentic, and so on, then he will explain and make notes and then give an outline of the problems contained in the Sanad and the observance of the hadith, and give his conclusions on the interpretation of the verse with the Hadith, which is reinforced by the opinions of mufassir.

\section{c. Qaul Sahābah}

Opinions from among the Companions of the Prophet. (qaul sahābah); namely when interpreting QS Yüsuf/ 12: 26. In this verse he interpreted it by quoting the words of a best friend, Ibn Abbas who said that what the witnesses meant in that verse was a child who was still in the cradle of his mother. In other verses, such as QS alNahl/ 16: 67 interpret the word sakr by including the opinion of Ibn Abbas and Ibn Mas'ud who say that sakr is khamr.

\section{d. Qiraat}

Regarding the source of the qiraat, it can be seen from its interpretation of QS al-Anbiya'/ 21: 80. In the interpretation of the verse he cites the opinion of the qari' seven groups regarding the word lituhs inakum, there are three namely: Firstly the majority of the qari 'seven except Ibn Amir and Ashim read the lafz with liyuhsinakum, that damir fa'il in this lafaz returned to David or al-Labus (armor). The word al-Labus is made mużakar because it considers the meaning, which is armor that is allowed. Both Ibn Amir and Hafsh from Ashim read lafz it lituhsinakum, namely damir fa'til on lafz this returned to al-Labuss, that lafz this is mu'annast, or to al-sunnah contained in lafź san'ata labüsin. Third Syu'bah read lafz with linahsinakum, namely damir fa'il on lafz this is the place of return, namely Allah.

He explained that the writing of his interpretation did not come out or could not be separated from its use of qira'ah sab'ah. He never relied on his interpretation by using qira'ah syażah. He further argues that perhaps in the commentary explanation in this book there is mention of weak qiraat, but only as a reinforcement to explain qira'ah sab'ah. He agreed with the scholars in the field of qiraat science that qira'ah Abu Ja'far and Ya'qub were not weak qiraat.

e. Verses

Not all interpretations include poetry, but including commentators who like to include poetry as a source of interpretation. It can be seen in several surahs, as in

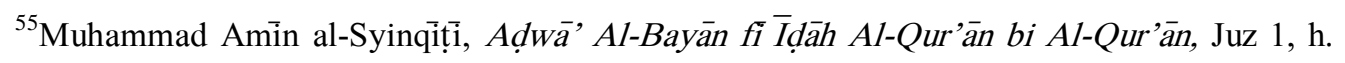
260.

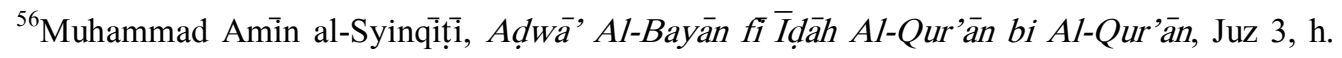
206.

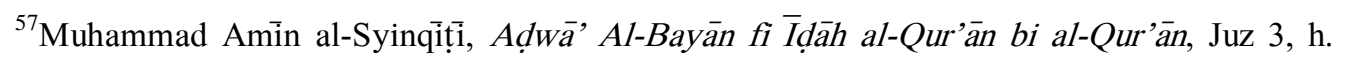
484.

${ }^{58}$ Muhammad Aminn al-Syinqīịì, Aḍ̂ā' Al-Bayān fī İdāh Al-Qur'ān bi Al-Qur’ān, Juz 1, h. 35
} 
Surah Al-An'àm/ 6: 59, ${ }^{59}$ "and in the sight of Allah are the keys of all that is unseen." In his interpretation, he included the expression Alqamah bin al-Tamimi: " whoever predicts with crows, for his salvation he will certainly be wretched ". then he continued with the poem about the Bani Lahab which is an Arab tribe famous for predicting "iyafah:" the news of the Bani Lahab has become corrupt, their speech is based on a passing bird ". Also quoted Amud al-Nasab's speech: "For Madlaj bin Bakr is to look for traces, as Bani Lahab did iyafah".

There is also a mention of the poem from Muhalhal "truly unrivaled for the Crusades, if the hiding place is revealed. It is truly incomparable to the Crusades, if magic shakes from behind. It is truly unparalleled for Crusades, great turmoil comes early in the morning". ${ }^{61}$ This expression is an explanation of its interpretation of the word ya'dilün in QS al-An'am/ 6: 165. He added the verse after describing QS al$\mathrm{R}$ um/ 30: 28 about comparison something can be interpreted as equivalent and the equation. According to him some Arabic scholars say "if the comparison is of the same type then it is' idl and if it comes from a different type then it is 'adl. Thus the use of poetic sources as sources of interpretation. ${ }^{62}$

\section{Comments on Al-Syinqīitī's Methodology}

The method have applied is not just one method, but several methods, tahtili and ijmăti. In the ahkām verse he uses the tahlili method, while the other verses are ijmâti. Observed his interpretation of the ahkäm verse, he said to be objective in giving views, but from his discussion of the background of his science and work, he remained the priority of his interpretation, he explained the opinions of the scholars of fiqh, but in the end he discussed more and provided reinforcement with Maliki's opinion. In addition, when discussing the lughawi (meaning of a lafaz), he included Zamakhsyari who contrast with him about majaz in the al-Qur'an, however, he still quoted his opinion as a language (meaning of lafaz) analysis, not majaz. This shows

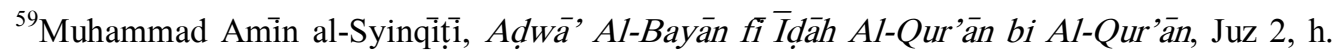
$130-133$.

${ }^{60}$ The meaning of 'iyafah is a fortune teller who uses help by throwing, knocking, through the stars and the causes commonly used in that regard. Like fortune telling with a bird that is claimed to reveal everything by seeing how it flies, where it sits, its name, its color, and its direction of flight. Actually al-Syinqit's explanation in this case is his interpretation of the unseen thing no one knows except Allah SWT, and all the means aimed at expressing it other than the revelation of God is a real error. From here so that he includes the hadith about people who come to the fort une teller to find out something, the prayer will not be accepted for forty days (HR. Muslim). Then he explained the understanding of the astrologer, and the path taken by the fortune teller from several ulama opinions such as al-Qurtubi and al-Baghawi. Included also include poems related to it. Muhammad Amin al-

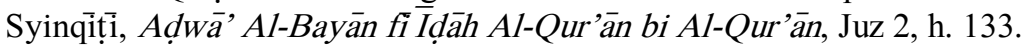

${ }^{61}$ The point of the poem is that the person they killed from Kabilah Bakr bin Wa'il with his brother Kalib who was killed by Jașasas bin Murrah al-Bakr is not enough and is not comparable to him in terms of glory.

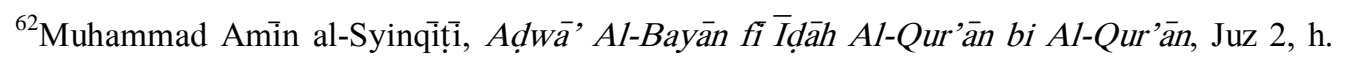
132-133.
} 
that he is trying to be objective because he still includes several opinions apart from his thoughts.

\section{E. Conclusion}

Al-Syinqiți interprets all the surahs of the al-Qur'an and according to the sequence of verses, even though he does not interpret all of the verses of each letter. His interpretation is more about the ahkäm verse, while other verses are more on the mujmal. Al-Syinqiti is one of the interpreter in modern period. The interpretation of the modern era is more in the nature of modern reasoning, because it is influenced by the nuances of thought at the time itself, namely the period of Islamic renewal. ${ }^{63}$ In contrast to Abduh, Rasyid Riḍa, or Amin al-Khuli, he prefers to follow previous commentators in understanding the meaning and instructions of the Qur'an. He emphasized more on the interpretation of al-Qur'an bi al-Qur'an and dedicated more to the concept of fiqhiyah. This is because of his background and activities as a teacher and as a qadi. However, he has a work that becomes a reference for his interpretation

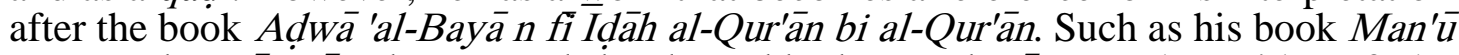

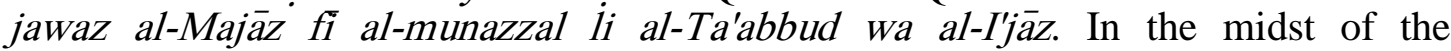
interpretive discourse that relies more on the interpretation of renewal, purpose of the interpreting is want the people to return to the al-Qur'an and sunnah, finding wisdom and law in the al-Qur'an.

\section{BIBLIOGRAPHY}

Djalal HA, Abdul. Urgensi Studi Tafsir Yang Mutakhir. Surabaya: IAIN Sunan Ampel, 1987.

Fath, Amir Faishol. The Unity of The Quran, terj. Nasiruddin Abas. Jakarta: Pustaka al-Kautsar, 2010.

Firman, Arham Junaidi. Studi Al-Qur'an;Teori dan Aplikasinya dalam Penafsiran Ayat Pendidikan. Yogyakarta: Diandra Kreatif, 2018.

Izzan, Ahmad. Metodologi Ilmu Tafsir . Bandung: Tafakur, t.t.

Khaeruman, Badri. Sejarah Perkembangan Tafsir Al-Qur'an. Bandung: Pustaka Setia, 2004.

Khalid, M. Rusydi. Manāhij Al-Mufassirin; Mengkaji Metode Para Mufassir. Jakarta: Mazhab Ciputat, 2016.

Mardan, Al-Qur'an Sebuah Pengantar. Jakarta: Mazhab Ciputat, 2015.

${ }^{63}$ Hadi Mutamam, "Kontribusi dan Kritik Tafsir Kontemporer”, Al-Fikr 17, no. 1 (2013) h. 157. 
Nata, Abudin. Metodologi Studi Islam. Cet. ke-18; Jakarta: Raja Grafindo Persada, 2011.

Nur, Afrizal. Khazanah dan Kewibawaan Tafsir bi Al-Ma’sur. Cet.ke-I; Riau: Fakultas UIN SUSKA RIU, 2015.

Qaradāwīi, Yūsūf. Kaifa Nata'amalu Ma'a Al-Qur'à Al-'Azīm, terj. Abdul Hayy alKattani. Cet.1; Jakarta: Gema Insani Press, 1999.

Qațtān, Manna'. Mabāhis fì Ulūm al-Qur'ān (Riyadh: Ma'had al'Āli lil Qaḍāi, t.t.

Al-Șadr, Muhammad Baqir. Madrasah Al-Qur'aniyah, terj. Hidayaturakhman. Jakarta: Risalah Masa, 1992.

Safrizal. “Tafsir Lughawi”, Al-Ta'lim 1, no. 5 (2013); h. 421-430.

Al-Șālih, Subhi. Mabāhis fì Ulūmi al-Qur’ān. Cet. ke-XVI, Beirut: Dār al-Ilmi Li alMalāyin, 1985.

Salim, Abd̆. Muin. dkk., Metodologi Penelitian Tafsìr Mauḍu'ì. Makassar: Pustaka al-Zikra, 2011.

Al-Syinqīịi, Muhammad Amin. Aḍ̂ā al-Bayān fī İdāh Al-Qur'ān bi Al-Qur'ān, Juz 1. Qāhirah: Dār al-Hadis, 2006.

------, Aḍ̛̂ā' Al-Bayān fì Ị̇āh Al-Qur'ān bi Al-Qur'ān, Juz 2. Qāhirah: Dār alHadis, 2006.

------, Aḍ̛wā' Al-Bayān fi Ị̇̂ăh Al-Qur'ān bi Al-Qur'ān, Juz 3. Qāhirah: Dār al-Hadìs, 2006.

------, Aḍ̂ā' Al-Bayān fị Ị̣̂āh Al-Qur'ān bi Al-Qur'ān, Juz 5. Qāhirah: Dār al-Hadis, 2006.

------, Adwā' Al-Bayān fì Ị̇āh Al-Qur'ān bi Al-Qur'ān, terj. Bari, dkk., Juz 2. Jakarta: Pustaka Azzam, 2007.

Al-Zahabi, Muhammad Husain. Al-Tafsir wa Al-Mufassirīn, Jilid 2. Kairo: Darul Hadis, 2005.

Al-Zarkasyi. Al-Burhān fì 'Ulūm Al-Qur'ān, Juz 1. Beirut: Dār al-Ma'ārif, $1391 \mathrm{H}$.

Al-Zarqani. Manāhl Al- 'Irfān. Beirut: Dār al-Ma'rifah, t.t.

Sofyan, Muhammad. Tafsir Wal Mufassirun. Cet.I; Medan: Perdana Publishing, 2015.

Srifariyati. "Manhaj tafsir Jami' Al-Bayan Karya Ibnu Jarir Al-Ṭabari”. Madaniyah 2, vol. 7 (2017); h. 319-342.

Subagyo, P. Joko. Metode Penelitian; teori dan Praktek. Jakarta: Rineka cipta, 1991.

Syukur, Abdul. “Mengenal Corak Tafsir Al-Qur'an”, Elfurqonia 1, no.1 (2015). 


\section{Guidelines}

\section{Submission of Article}

urnal Adabiyah welcomes the articles submission with the main themes on Humanities and Islamic Studies with the emphasis on interdisciplinary and intertextuality approach. Adabiyah is thematicly published twice in a year. ie the theme of the humanities in June and the Islamic Study in December.

Themes related to Islamic Studies are textual studies, scriptural traditions, Islamic law, and theology; and those related to Humanities are language, literature, history, and culture. This scholarly journal Guarantees that the editor decision based on the peer review results will not exceed 30 days from the paper submission date.

Authors are invited to read our archives; to find the relevant topics for the journal, and to submit complete unpublished scientific researches, which are not under review in any other conferences or academic journal.

\section{PUBLICATION ETHIC}

Publication Ethic and Malpractice Statement

Jurnal Adabiyah is a peer-reviewed journal, published twice a year by the Faculty of Adab and Humaniora, Alauddin State Islamic University of Makassar Indonesia. It is available online as open access sources as well as in print. This statement clarifies ethical behaviour of all parties involved in the act of publishing an article in this journal, including the author, the editor-in-chief, the Editorial Board, the reviewers, and the publisher. This statement is based on COPE's Best Practice Guidelines for Journal Editors.

Ethical Guideline for Journal Publication

The publication of an article in Jurnal Adabiyah, is an essential building block in the development of a coherent and respected network of knowledge. It is a direct reflection of the quality of the work of the authors and the institutions that support them. Peer-reviewed articles support and embody the scientific methods. It is therefore important to agree upon standards of expected ethical behavior for all parties involved in the act of publishing: the author, the editor, the reviewer, the publisher, and the society. As the publisher of Jurnal Adabiyah, the Faculty of Adab and Humaniora takes its duties of guardianship over all stages of publishing seriously and it recognizes its ethical and other responsibilities. The Faculty of Adab and Humaniora committed to ensuring that advertising, reprint or other commercial revenue has no impact or influence on editorial decisions.

\section{Publication Decisions}

The editors of Jurnal Adabiyah is responsible for deciding which articles submitted to the journal should be published. The validation of the work in question and its importance to researchers and readers must always drive such decisions. The editors may be guided by the policies of the journal's editorial board and constrained by such legal requirements as shall then be in force regarding libel, copyright infringement, and plagiarism. The editors may confer with other editors or reviewers in making their decisions.

\section{Plagiarism Screening}

It is basically author's duty to only submit a manuscript that is free from plagiarism and academically malpractices. The editor, however, will check all submitted papers through Turnitin.

\section{Fair Play}

An editor at any time evaluates manuscripts for their intellectual content without regard to race, gender, sexual orientation, religious belief, ethnic origin, citizenship, or political philosophy of the authors. 


\section{Confidentiality}

The editors and any editorial staff must not disclose any information about a submitted manuscript to anyone other than the corresponding author, reviewers, potential reviewers, other editorial advisers, and the publisher, as appropriate.

\section{Disclosure and Conflicts of Interest}

Unpublished materials disclosed in a submitted manuscript must not be used in editors' own research without the express written consent of the author.

\section{DUTIES OF AUTHORS}

\section{Reporting Standards}

Authors of reports of original research should present an accurate account of the work performed as well as an objective discussion of its significance. Underlying data should be represented accurately in the paper. A paper should contain sufficient detail and references to permit others to replicate the work. Fraudulent or knowingly inaccurate statements constitute unethical behaviour and are unacceptable.

\section{Originality and Plagiarism}

The authors should ensure that they have written entirely original works, and if the authors have used the work and/or words of others that this has been appropriately cited or quoted.

\section{Multiple, Redundant, or Concurrent Publication}

An author should not in general publish manuscripts describing essentially the same research in more than one journal or primary publication. Submitting the same manuscript to more than one journal concurrently constitutes unethical publishing behaviour and is unacceptable.

\section{Acknowledgement of Sources}

Proper acknowledgment of the work of others must always be given. Authors should cite publications that have been influential in determining the nature of the reported work.

\section{Authorship of the Paper}

Authorship should be limited to those who have made a significant contribution to the conception, design, execution, or interpretation of the reported research. All those who have made significant contributions should be listed as co-authors. Where there are others who have participated in certain substantive aspects of the research project, they should be acknowledged or listed as contributors. The corresponding author should ensure that all appropriate co-authors and no inappropriate co-authors are included on the paper, and that all co-authors have seen and approved the final version of the paper and have agreed to its submission for publication.

\section{Disclosure and Conflicts of Interest}

All authors should disclose in their manuscript any financial or other substantive conflict of interest that might be construed to influence the results or interpretation of their manuscript. All sources of financial support for the project should be disclosed.

\section{Fundamental errors in Published Works}

When an author discovers a significant error or inaccuracy in his/her own published work, it is the author's obligation to promptly notify the journal editor or publisher and cooperate with the editor to retract or correct the paper.

\section{PLAGIARISMIE}

It is basically author's duty to only submit a manuscript that is free from plagiarism and academically malpractices. The editor, however, will check all submitted papers through Turnitin. 


\section{AUTHOR GUIDELINES}

\section{Guidelines for online submission:}

1. Author should first register as Author to the website of Jurnal Adabiyah. Click the menu "register" to register as an author.

2. Once after the author is registered, please login to the website of Jurnal Adabiyah and submit the article through online submission (with the stat us of active submissions).

3. The article should follow the standard template of Jurnal Adabiyah provided in the website.

4. The citation and bibliography should follow the Turabian citation style.

5. Author is restricted not to send his/her article to another journal before having confirmation from the editorial team (approximately 4 weeks right after the article submitted).

6. Author should follow editorial decisions and recommendations related to the article completion. All reviews and assessements will be informed through online submission.

Article submitted to Jurnal Adabiyah editorial board must follow these guidelines:

1. Article should be based on the scientific research in the field humanities and Islamic studies;

2. Article must be an original work and has not been previously published;

3. Article should be written in Arabic or English languages;

4. Article must be typed in one-half spaced on A4-paper size;

5. Article's length is about $6,000-10,000$ words;

6. All submission must include a 150-250 word abstract;

7. Abstract should be written in 3 languages; Arabic, English, and Bahasa;

8. Full name(s) of the author(s) must be stated, along with his/her/their institution and complete address;

9. All submission should be in OpenOffice, Microsoft Word, RTF, or WordPerfect document file format;

10. Bibliographical reference must be noted in footnote and bibliography according to Jurnal Adabiyah style. In addition, it is suggested for author(s) to use reference manager tools such

\section{as MENDELEY or 7 otero}

When a source is cited for the first time, full information is provided: full name(s) of author(s), title of the source in italic, place of publication, publishing company, date of publication, and the precise page that is cited. For the following citations of the same source, list the author's last name, two or three words of the title, and the specific page number(s). The word ibid., op.cit., and loc.cit. are may not be used any more.

\section{Example in footnotes:}

${ }^{1}$ Mircea Eliade (ed.), The Encyclopedia of Religion, vol. 8 (New York: Simon and Schuster, 1995), h. 18.

${ }^{2}$ Norman Daniel, Islam and the West (Oxford: One World Publications, 1991), h. 190.

${ }^{3}$ Syeikh Ja'far Subhāni, Mafăhim Al-Qur'ān (Beirut: Mu'assasah Al-Tarīkh Al-'Arabī, 2010)., Juz 5, h. 231. 
${ }^{4}$ Syeikh Ja'far Subhānī, Mafāhim Al-Qur'ān, h. 8-9.

\section{Example in bibliography:}

Subhānī, Syeikh Ja'far. Mafăhim Al-Qur'ān. Beirut: Mu'assasah Al-Tarīkh Al-’Arabī, 2010.

Eliade, Mircea (ed.). The Encyclopedia of Religion, vol. 8. New York: Simon and Schuster, 1995.

Daniel, Norman. Islam and the West. Oxford: One World Publications, 1991.

Shihab, Muhammad Quraish. Sunnah-Syiah Bergandengan Tangan: Mungkinkah? Kajian Atas Konsep Ajaran Dan Pemikiran. Cet. III. Jakarta: Lentera Hati, 2007.

\section{Detail informations of the footnotes:}

1. Holy book

Al-Qur'ân, Al-Baqarah/2: 185.

Perjanjian Baru, Mrk. 2: 18.

2. Qur'anic translation

${ }^{1}$ Departemen Agama RI, al-Qur'an dan Terjemahannya (Jakarta: Darus Sunnah, 2005), h. 55.

3. Book

${ }^{1}$ Muḥammad 'Ajjaj al-Khațib, Ușl al-Hadith: 'Ulumuh wa Mușțalaḥ uh (Beirut: Dâr al-Fikr, 1989), h. 57.

4. Translation Books

${ }^{1}$ Toshihiko Izutsu, Relasi Tuhan dan Manusia: Pendekatan Semantik terhadap al-Qur'an, terj. Agus Fahri Husein dkk (Yogyakarta: Tiara Wacana, 2003), h. 14.

5. Voluminous book

${ }^{1}$ Muḥammad al-Ṭâhir b. 'Ashur, al-Tahrīir wa al-Tanwīr, Vol. 25 (Tunisia: Dâr al-Suhûn, 2009), h. 76.

${ }^{1}$ Muḥammad b. Ismā‘īl al-Bukharī, al-Jami‘ al-Ṣaḥịh, Vol. 2 (Beirut: Dar al-Kutub al-‘Ilmı́yah, 1999), h. 77.

6. Article in book

${ }^{1}$ Sahiron Syamsuddin, "Metode Intratekstualitas Muhammad Shahrur dalam Penafsiran al-Qur'an" dalam Abdul Mustaqim dan Sahiron Syamsuddin (eds.), Studi al-Qur'an Kontemporer: Wacana Baru Berbagai Metodologi Tafsir (Yogyakarta: Tiara Wacana, 2002), h. 139.

7. Article in encyclopaedia

${ }^{1}$ M. Th. Houtsma, "Kufr" dalam A. J. Wensinck, at al. (ed.), First Encyclopaedia of Islam, Vol. 6 (Leiden: E.J. Brill, 1987), h. 244.

8. Article in journal

${ }^{1}$ Muhammad Adlin Sila, "The Festivity of Maulid Nabi in Cikoang, South Sulawesi: Between Remembering and Exaggerating the Spirit of Prophet", Studia Islamika 8, no. 3 (2001): h. 9.

9. Article in mass media

${ }^{1}$ Masdar F. Mas'udi, "Hubungan Agama dan Negara”, Kompas, 7 Agustus 2002. 
10. Article in Internet

${ }^{1}$ Muhammad Shahrūr, "Reading the Religious Teks: a New Approach" dalam http://www.shahrour.org/25 Februari 2010/diakses 5 Juni 2010.

11. Thesis or dissertation

${ }^{1}$ Syahruddin Usman, "KinerjaGuru Penddikan Agama Islam pada SMAN dan SMKN Kota Makassar”, Disertasi (Makassar: PPs UIN Alauddin, 2010), h. 200.

\section{COPYRIGHT NOTICE}

Authors who publish with this journal agree to the following terms:

1) Authors retain copyright and grant the journal right of first publication with the work simultaneously licensed under a Creative Commons Attribution License that allows others to share the work with an acknowledgement of the work's authorship and initial publication in this journal.

2) Authors are able to enter into separate, additional contractual arrangements for the non-exclusive distribution of the journal's published version of the work (e.g., post it to an institutional repository or publish it in a book), with an acknowledgement of its initial publication in this journal.

3)Authors are permitted and encouraged to post their work online (e.g., in institutional repositories or on their website) prior to and during the submission process, as it can lead to productive exchanges, as well as earlier and greater citation of published work (See The Effect of Open Access). 